\title{
Monetarists and Keynesians
}

THEIR CONTRIBUTION TO MONETARY THEORY

\section{BRIAN MORGAN}

Senior Lecturer in Economics

The Polytechnic of Central London

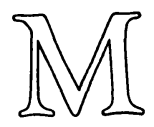




\section{(C) Brian Morgan 1978}

All rights reserved. No part of this publication may be reproduced or transmitted, in any form or by any means, without permission.

First edition 1978

Reprinted 1979, 1980, 1981, 1982

\section{Published by}

THE MACMILLAN PRESS LTD

London and Basingstoke

Companies and representatives

throughout the world

\section{British Library Cataloguing in Publication Data}

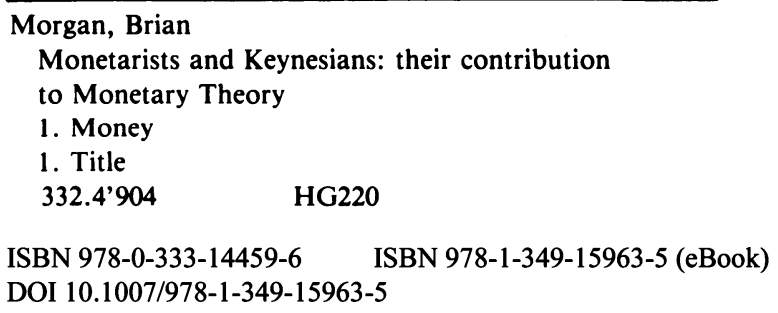

The paperback edition of this book is sold subject to the condition that it shall not, by way of trade or otherwise, be lent, re-sold, hired out, or otherwise circulated without the publisher's prior consent in any form of binding or cover other than that in which it is published and without a similar condition including this condition being imposed on the subsequent purchaser. 
To the memory of my father

E. J. MORGAN 


\section{Contents}

Preface and Introduction vii

1 An Overview 1

2 Classical and Keynesian models 9

3 A Consensus? 45

4 The Rise of Monetarism $\quad 68$

$\begin{array}{lll}5 & \text { A Reappraisal } & 104\end{array}$

6 Concluding Notes: Is it Relevant? 152

$\begin{array}{ll}\text { Notes and References } & 167\end{array}$

$\begin{array}{lr}\text { Bibliography } & 172\end{array}$

Index of Subjects 179

Index of Names 183 


\section{Preface and Introduction}

This book developed from a course of lectures, given first at Middlesex Polytechnic and more recently at The Polytechnic of Central London, which attempted to introduce undergraduates to monetary theory in the light of the continuing debate over the meaning of the Keynesian revolution.

The message underlying this book is that Keynes, in The General Theory of Employment, Interest and Money, revolutionised economic theory and developed a realistic theory of accumulation in a modern, money-using capitalist economy. Keynes's theory focused on the problems of uncertainty, expectations, wealth, interest and money in disequilibrium situations and it is argued that this theoretical approach is far better equipped for solving current economic problems than that offered by either modern-day Keynesians or Monetarists. In fact, the debate between Monetarists and Keynesians is a difficult one to resolve, precisely because both approaches are firmly based on equilibrium theory. Specifically their theoretical foundations are those of the Walrasian general equilibrium system and it is this system that underlies the $I S / L M$ model within which the analysis of both schools is formulated. However, the $I S / L M$ model is inappropriate for illustrating Keynes's theoretical innovations because it largely assumes away the problems of uncertainty and expectations which bedevil capitalist systems and with which Keynes was grappling.

It will be obvious to the reader that this interpretation of Keynes owes much to the writings of Axel Leijonhufvud and in fact one of my aims in writing this book has been to place students in a better position to read and understand both Keynes's original work (now published in full by the Royal Economic Society) and Leijonhufvud's now classic doctoral thesis On Keynesian Economics and the Economics of Keynes (described by Harry Johnson as a 'monumentally scholarly study').

However, this book probably would not have been written without the valuable insights into monetary theory provided by my former 
teacher at the London School of Economics, Mr Laurence Harris. I would also like to acknowledge my debt to Professor David W. Pearce for being infinitely patient with an awkward author, to my students who have read and criticised the manuscript through numerous revisions and to Christine Morgan for some valuable advice in the preparation of the final chapters. Responsibility for errors of omission and commission of course remain with the author.

June 1977

Brian Morgan 